\title{
Assessment of oilseed raw materials for industrial crops, taking into account the demand by vegetable oil producers
}

\author{
E.I. Lupova ${ }^{1}, A . V$. Novikova $^{2, *}$ and D.V. Vinogradov ${ }^{1}$ \\ ${ }^{1}$ Department of Agronomy and Agrotechnologies, Ryazan State Agrotechnological University named after P.A. Kostychev, \\ Ryazan 390044, Russia \\ 2 Department of Technology for Storage and Processing of Fruit and Vegetable and Crop Production, Russian State Agrarian \\ University - Moscow Agricultural Academy named after K.A. Timiryazev, Moscow 127550, Russia
}

\begin{abstract}
Developments in selection and emergence of new varieties and hybrids of oilseeds, which have a better ratio of the fatty acid composition of the oil, make is possible to promote such types of crops as camelina, colza, rapeseed and others. The paper presents an analysis of the quality of new and promising varieties and hybrids of oilseeds, which, according to their morphological and biological characteristics, are successfully cultivated in conditions of the Non-Chernozem Zone of Russia. It is confirmed that oil quality is due to genetic characteristics of the variety and hybrid. The quality of seeds of spring rapeseed Ratnik, Cyclus KL, Curry KL, Salsa KL, Cultus KL, Ozorno, Cebra and other studied varieties and hybrids of the 00 type are close to olive oil in their fatty acid composition and are not inferior to the quality of sunflower oil. There is a high content of important C18:1 oleic acid in oil of rapeseed (59-65\%), and a low content of the total of C16:0 palmitic + C18:0 stearic (5.5-6.0 \%). The data on the high quality of camelina oil are presented, which allows the use of varieties Yubilyar and Veles for production of vegetable oil with a high content of unsaturated acids for food purposes. The work discusses the current restrictive norms for the supply of oilseeds and determining the standard weight for oil refining enterprises.
\end{abstract}

\section{Introduction}

To work efficiently, human body needs a diet that is rich in essential fatty acids, such as oleic, linoleic and linolenic acids. The most valuable one is oleic acid, being a monounsaturated fatty acid and one of the main components of vegetable oil from rape, sunflower or flax. It is an omega-9 acid [1]. The oilseeds group is unique in this regard and it compares favorably with other groups of crops [2-4].

The importance was determined for the group of polyunsaturated fatty acids omega-3 (alpha-linolenic and eicosapentaenoic) and the group of omega- 6 (linoleic, linolenic), which cannot be synthesized in the human body. Omega groups must enter the human body with food, and therefore are called indispensable $[5,6]$.

Deficiency of essential fatty acids is observed in people living in large cities and people who consume food with a long shelf life. In a case of a shortage of essential fatty acids, a person's endurance decreases, skin dryness increases, brittle hair and weakness of memory appear, probability of cardiovascular diseases and arthritis increases, diabetes is often observed, allergies are aggravated and digestion worsens. Saturated fatty acids, palmitic and stearic, are found in animal fats and are formed in the human body [7]. The total amount of essential fatty acids characterizes the content of vitamin $\mathrm{F}$ in food.
With the development of selection and the emergence of new varieties and hybrids of oilseeds, which have a better ratio of the fatty acid composition of the oil, it was possible to promote such types as oil flax, camelina, colza an crambe [8].

The development of the processing industry and the improvement of engineering thought also contributed greatly to the promotion of oilseeds, especially in terms of the quality of pressing oilseeds and oil clarification, refining and deodorization.

Note that the shelf life of vegetable oils depends on linoleic acid, which increases oxidation resistance. This vegetable oil is rich in natural antioxidants and tocopherols, which benefit the human body. Flax oils, some varieties and hybrids of camelina, rapeseed and sunflower have a high linoleic acid content [8].

\section{Problem statement}

The type of vegetable raw materials from which the oils are obtained, as well as the influence of environmental factors and agricultural technologies determine the physical, chemical and biological properties of vegetable oils.

The direction of development of oilseed breeding is to develop and introduce varieties and hybrids with a set of specified characteristics, including the presence or lack of specific fatty acids. Elements of agricultural

* Corresponding author: navbaa@mail.ru 
technology, weather conditions, the technology for oil production, etc. are also involved [9-11]. This determined the relevance and importance of the research.

\section{Materials and methods}

Field studies were conducted at the experimental agrotechnological station of Ryazan State Agrotechnological University named after P.A. Kostychev (FSBEI HE RSATU) in Ryazan region. They were carried out in accordance with generally accepted methods and recommendations. Observations in experiments, records and analyses were carried out according to generally accepted methods and GOSTs $[12,13]$.

Oil crops were grown on dark gray forest loamy soils with 3.0-3.3 \% humus content in the arable horizon, typical for this type of soil in the region. The soil medium reaction was acidic $\left(\mathrm{pH}_{\mathrm{Kcl}}-5.0\right)$. Hydrolytic acidity was low and did not exceed $2.6 \mathrm{MEq} / 100 \mathrm{~g}$ of the soil.

The total absorbed bases were $15 \mathrm{MEq} / 100 \mathrm{~g}$ of soil and the degree of soil saturation with bases was not more than $70 \%$. The content of elements in the arable horizon of the soil was as follows: phosphorus (on average $120 \mathrm{mg} / \mathrm{kg}$ of soil) and potassium (on average $150 \mathrm{mg} / \mathrm{kg}$ of soil) corresponded to increased (class IV), nitrogen $(50 \mathrm{mg} / \mathrm{kg}$ of soil) corresponded to low (class II). The level of agroecological loads in oilseed production technology influenced the biochemical parameters of gray forest soil [14].

The growth and development of oilseeds depended on the soil and climatic conditions of the growing season $[15,16]$. Weather conditions during the years of research were the following: 2018 (HTI was 0.64) and 2019 (HTI was 1.1) were warm, with a predominance of elevated temperatures, but insufficient moisture in the first half of the oilseed vegetation.

Agro-technical measures for the cultivation of oilseeds were in accordance with recommendations adopted in the Non-Chernozem Zone of Russia.

Indicators of oil content, protein and fatty acid composition of oilseeds of the Cruciferous family are given for options of maximum productivity by varieties and hybrids and at the design level of mineral nutrition and for the first sowing date, the first decade of May. The dose $\mathrm{N}_{180} \mathrm{P}_{120} \mathrm{~K}_{60}$ was obtained when calculating the norms for applying mineral fertilizers, taking into account the adjustment, and calculating the balance of nutrients on gray forest soils in the conditions of the experimental agrotechnological station in Ryazan region.

The quality of oil seeds was analyzed in laboratories of the Station of the Agrochemical Service "Ryazan", the testing facility of State Budgetary Institution of Ryazan region Ryazan Regional Veterinary Laboratory, laboratories of JSC "Kubanmaslo-EMZ" in Efremov and Venev towns of Tula region and FSBEI HE RSATU. The equipment employed included infrared analyzer Spectran-119M, chromatograph, enzyme-linked immunosorbent analyzer AIFR-01 Uniplan and other devices for gas-liquid chromatography and glucose test.

\section{Results and discussion}

Camelina oil in our research contained more than $50 \%$ of polyunsaturated fatty acids, omega- 3 and omega- 6 with a large number of natural antioxidants that prevent oxidation of insufficiently stable essential fatty acids and oil spoilage. These substances protect fatty acids from being destroyed by exposure to high temperatures, light and oxygen.

A wide variety of lipids, their complexity and various variants of bonds with the main tissue led to the fact that until today there is no strict chemical classification of fats. Lipids are divided into different groups depending on the biochemical function.

The biological value of vegetable oil as a food product is largely determined by the positional location of fatty acids in triacylglycerols, primarily the content of C18:2 linoleic acid and its ratio with other fatty acids. The need of the human body for oils in a balanced composition is as follows: $20-30 \%$ linoleic acid, $40-60 \%$ oleic and not more than $20 \%$ saturated acids.

A qualitative composition of varieties and hybrids of oil crops grown in conditions of the experimental agrotechnological station in 2017-2019 is shown below. Prototypes were grown in the first sowing period starting from the first decade of May and then their mineral nutrition was estimated (Table 1).

Table 1. Oil content and fatty acid composition of oilseeds of the Cruciferous family grown in the experimental agrotechnological station of Ryazan region

\begin{tabular}{|c|c|c|c|c|c|c|c|c|}
\hline \multirow[t]{2}{*}{ Crop } & \multirow{2}{*}{$\begin{array}{l}\text { Variety } \\
\text { hybrid }\end{array}$} & \multirow[b]{2}{*}{ 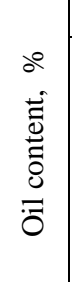 } & \multicolumn{6}{|c|}{ Acid, \% } \\
\hline & & & 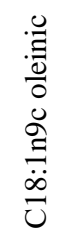 & 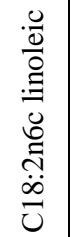 & 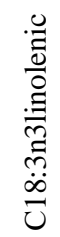 & 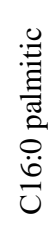 & 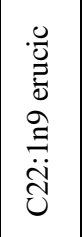 & 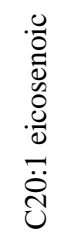 \\
\hline \multirow{2}{*}{$\begin{array}{c}\text { Spring } \\
\text { camelina }\end{array}$} & Veles & 38.0 & 13.8 & 18.4 & 34.8 & 5.5 & 3.0 & 13.9 \\
\hline & Yubilyar & 38.9 & 14.1 & 17.8 & 35.5 & 5.6 & 1.1 & 13.3 \\
\hline Oil radish & Fiolina & 38.1 & 33.1 & 16.7 & 14.7 & 6.3 & 13.4 & 8.7 \\
\hline \multirow{3}{*}{$\begin{array}{l}\text { White } \\
\text { mustard }\end{array}$} & Rapsodiya & 30.1 & 25.8 & 8.8 & 10.6 & 2.7 & 34.8 & 10.2 \\
\hline & Lucia & 30.1 & 34.1 & 8.6 & 9.5 & 2.5 & 27.6 & 10.7 \\
\hline & Chaika & 30.5 & 23.5 & 7.9 & 12.0 & 2.4 & 37.6 & 9.0 \\
\hline \multirow{7}{*}{$\begin{array}{c}\text { Spring } \\
\text { rapeseed }\end{array}$} & Ratnik & 43.0 & 64.3 & 15.7 & 10.5 & 4.7 & traces & 1.3 \\
\hline & Cyclus KL & 46.5 & 60.3 & 17.9 & 10.4 & 3.9 & traces & 1.2 \\
\hline & Curry KL & 43.8 & 60.6 & 17.7 & 10.2 & 4.2 & traces & 1.0 \\
\hline & Salsa KL & 45.0 & 59.4 & 18.3 & 10.2 & 4.3 & \begin{tabular}{|l|}
- \\
\end{tabular} & 1.1 \\
\hline & Cultus KL & 45.3 & 63.0 & 17.9 & 10.4 & 3.9 & - & 1.3 \\
\hline & Ozorno & 47.1 & 60.2 & 17.9 & 10.4 & 3.8 & traces & 1.4 \\
\hline & Cebra & 43.4 & 62.9 & 18.2 & 7.4 & 3.7 & traces & 1.2 \\
\hline $\begin{array}{c}\text { Spring } \\
\text { colza }\end{array}$ & $\begin{array}{c}\text { Yantarnay } \\
\text { a }\end{array}$ & 40.5 & 63.4 & 23.2 & 9.8 & 2.4 & - & 0.4 \\
\hline
\end{tabular}

When analyzing camelina oil, one can note a low content of C22:1 erucic fatty acid, which allows using varieties Yubilyar and Veles for production of vegetable oil with a high content of unsaturated acids for food purposes. Nevertheless, due to a high content of C18:2 linoleic acid (17-20\%), camelina oil is unstable to oxidation and has a specific taste. 
Oils of spring rapeseed varieties and hybrids Ratnik, Cyclus KL, Curry KL, Salsa KL, Cultus KL, Ozorno, Cebra and other studied ones of the 00 type are close to olive oil in their fatty acid composition and are not inferior to the quality of sunflower oil. Rapeseed oil is characterized by a high content of important $\mathrm{C} 18: 1$ oleic acid (59-65\%) and a low content of the combination of C16:0 palmitic + C18:0 stearic acids (5.5-6.0\%).

The right choice of varieties and hybrids of any crop is crucial in achieving profitability. Thanks to the work of breeders, a genetically stable potential productivity is improved, which is expressed not only in increased yield, but also in the increase of the quality of oil seeds, adaptation to growing conditions, and resistance to diseases and stress factors.

Table 2 presents the yield and oil content of experimental crops of spring rapeseed by years of research in the experimental agrotechnological station at demonstration crops of Ryazan region, when sowing on May 4-7 with $\mathrm{N}_{90} \mathrm{P}_{60} \mathrm{~K}_{60}$.

Table 2. The average yield and oil content of spring rapeseed in conditions of the experimental agrotechnological station of Ryazan region

\begin{tabular}{|c|c|c|c|c|c|}
\hline $\begin{array}{c}\text { Variety / } \\
\text { hybrid }\end{array}$ & 2015 & 2016 & 2017 & 2018 & 2019 \\
\hline \multirow{2}{*}{ Ratnik } & 22.0 & 23.4 & 15.7 & 18.7 & 15.2 \\
\hline & $\overline{43.3}$ & 42.7 & $\overline{43.6}$ & $\overline{44.5}$ & $\overline{43.0}$ \\
\hline \multirow{2}{*}{ Rythm } & 22.2 & 19.6 & 17.0 & 23.0 & \multirow{2}{*}{ 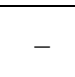 } \\
\hline & $\overline{-}$ & $\overline{40.0}$ & $\overline{42.6}$ & $\overline{43.5}$ & \\
\hline \multirow{2}{*}{ Salsa KL } & 25.4 & $\underline{26.3}$ & 19.4 & 22.7 & $\underline{19.0}$ \\
\hline & $\overline{47.0}$ & $\overline{45.4}$ & $\overline{46.7}$ & 42.9 & 45.0 \\
\hline \multirow{2}{*}{ Mobil KL } & $\underline{25.1}$ & 25.7 & 20.1 & $\underline{19.4}$ & 22.9 \\
\hline & - & 44.9 & 44.7 & 43.0 & 48.1 \\
\hline \multirow{2}{*}{ Ozorno } & 26.7 & $\underline{25.9}$ & 23.3 & $\underline{21.7}$ & $\underline{18.0}$ \\
\hline & 47.2 & 48.0 & 50.0 & 43.6 & 47.1 \\
\hline
\end{tabular}

Note: The numerator presents the yield, $\mathrm{dt} / \mathrm{ha}$ and the denominator presents oil content, $\%$.

The oil content of rapeseed in the studied varieties varied in the range of 40-50\%. Hybrid Ozorno possessed high oil content.

Table 2 shows that all the hybrids and varieties presented have stable productivity and require further testing in the region.

Currently, for rapeseed and colza (GOST 10583-76, GOST 12098-76), mainly the following restrictive norms are applied to the supply of oilseeds and the determination of the standard weight for oilseed processing enterprises (Table 3 ).

When accepting rapeseed and colza, other quality indicators must comply with requirements of GOST for crops and SanPiN 2.3.2. 1078-01. In cases where seeds are supplied with the oil content below the established restrictive norms, or exceeding the restrictive norm of the acid number, it is common for large processing plants do reduce the assumed weight of oil raw materials by $1 \%$ for each percentage point reduction in the oil content.

If the supply of raw materials is in excess of the restrictive norm of oil impurity, then the assumed weight of the raw material is commonly reduced by $0.5 \%$ for each percentage point of the excess over the norm of oil impurity. The supply of raw materials with oil impurity of more than $7 \%$ often requires additional negotiations.

Table 3. Restrictive norms for the supply of rapeseed and colza oilseeds

\begin{tabular}{|c|c|c|c|}
\hline \multirow{2}{*}{ Parameter } & \multicolumn{2}{|c|}{ Norms } & \multirow{2}{*}{ GOST } \\
\cline { 2 - 3 } & Rape & Colza & \\
\hline Humidity, \% & 7.0 & 8.0 & $10856-96$ \\
\hline $\begin{array}{c}\text { Weed } \\
\text { contamination, \% }\end{array}$ & 3.0 & 3.0 & $10854-88$ \\
\hline Oil impurity, \% & 6.0 & 6.0 & $10854-88$ \\
\hline $\begin{array}{c}\text { Acid number, } \\
\text { mgKOH/g }\end{array}$ & 3.0 & 3.0 & $10858-77$ \\
\hline $\begin{array}{c}\text { Crude fat to } \\
\text { absolutely dry } \\
\text { matter, \% }\end{array}$ & $\begin{array}{c}\text { not less } \\
\text { than 44.0 }\end{array}$ & $\begin{array}{c}\text { not less } \\
\text { than 43.0 }\end{array}$ & $10857-64$ \\
\hline $\begin{array}{c}\text { Erucic acid, \% } \\
\text { not more } \\
\text { than 2.0 }\end{array}$ & $\begin{array}{c}\text { not more } \\
\text { than 2.0 }\end{array}$ & $30089-93$ \\
\hline Pest infestation & not allowed & not allowed & $10853-99$ \\
\hline Chlorophyll mg/kg & $\begin{array}{c}\text { not more } \\
\text { than 5 }\end{array}$ & $\begin{array}{c}\text { not more } \\
\text { than 5 }\end{array}$ & $51485-99$ \\
\hline
\end{tabular}

Oilcake can be used as a component in the preparation of animal feed, for example, replacing soybean meal with rapeseed or camelina ones.

Note that the meal of rapeseed, camelina and other cruciferous crops should contain no more than $1 \%$ glucosinolates. If the content of glycosinolates in the meal is more than $1 \%$, then it can be used only in a mixture with feed for ruminants. In the studied varieties of camelina, oilcake and oilseed meal practically did not contain glycosinolates $(0.3-0.7 \%)$. It is recommended to use the obtained camelina cake for direct introduction into the ration of animals and for the production of animal feed.

The development of the processing industry and the improvement of engineering, especially in terms of the quality of pressing oilseeds and oil purification, refining and deodorizing, has greatly contributed to the promotion of oilseeds.

For example, the processing of flax seeds, in the recent past, remained very problematic. Flaxseed oil, which came out from under the presses, was of low quality for food purposes, due to the oxidation of unsaturated fatty acids in it, primarily linolenic, with free access of oxygen. As a result, linseed oil often had a bitter taste and a fishy smell. With the advent of new varieties (Sanlin, VNIIMK-620, LM-98), with a low content of linolenic acid, this disadvantage was eliminated. Therefore, it is important to increase the concentration of linoleic acid and reduce the content of undesirable linolenic acid, which affects the organoleptic qualities during long-term storage of vegetable oil.

The biological value of vegetable oil as a food product is largely determined by the positional location of fatty acids in triacylglycerols, primarily the content of linoleic acid $\mathrm{C} 18: 2$ and its ratio to other fatty acids. The human body needs oils in a balanced composition: 20$30 \%$ linoleic acid, 40-60\% oleic acid and no more than $20 \%$ saturated acids (Table 4 ). 
Table 4. Oil content and composition of the main fatty acids in the varieties of oilseed flax cultivated in the Ryazan region

\begin{tabular}{|c|c|c|c|c|c|c|}
\hline \multirow[t]{2}{*}{ Crop } & \multirow{2}{*}{$\begin{array}{l}\text { Variety } \\
\text { hybrid }\end{array}$} & \multirow[b]{2}{*}{ 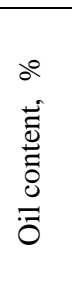 } & \multicolumn{4}{|c|}{ Acid, $\%$} \\
\hline & & & 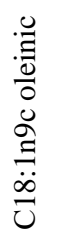 & 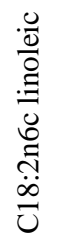 & 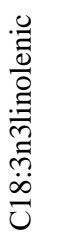 & 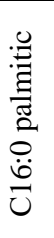 \\
\hline \multirow{4}{*}{$\begin{array}{c}\text { Flax } \\
\text { oilseed }\end{array}$} & LM 98 & 42.0 & 12.3 & 69.0 & 7.0 & 6.0 \\
\hline & Source & 45.3 & 14.1 & 68.7 & 4.3 & 6.6 \\
\hline & $\begin{array}{l}\text { VNIIMK } \\
620\end{array}$ & 43.6 & 14.1 & 68.9 & 4.2 & 6.4 \\
\hline & Sanlin & 40.1 & 18.3 & 65.9 & 7.0 & 6.0 \\
\hline
\end{tabular}

The accumulation of fatty acids occurs at different stages of maturation of oilseeds. In the early periods of seed formation, saturated and oleic acids predominate, later linolenic and linoleic acids are formed.

In experiments, the quality of the oil was mainly due to the genetic characteristics of the variety. At the same time, with each subsequent sowing period, there was a slight $(0.5-1.1 \%)$ increase in the content of saturated acids, primarily stearic acid, in rapeseed and flaxseed vegetable oil.

Note that the shelf life of vegetable oils depends on linoleic acid, which increases the resistance to oxidation. This vegetable oil is rich in natural antioxidantstocopherols, which are beneficial to the human body. High content of linoleic acid in flax oils, some varieties and hybrids of ginger, rapeseed, sunflower.

\section{Conclusion}

Thus, the quality of oil was mainly defined by genetic characteristics of the variety and hybrid. The quality of seeds for spring rapeseed varieties and hybrids Ratnik, Cyclus KL, Curry KL, Salsa KL, Cultus KL, Ozorno, Cebra and others of the 00 type are close to the olive oil in their fatty acid composition and are not inferior to the quality of sunflower oil. Rapeseed oil is characterized by a high content of important C18:1 oleic acid (59-65\%) and a low content of the combination of $\mathrm{C} 16: 0$ palmitic + C18:0 stearic acids (5.5-6.0\%).

The quality of camelina oil has a low content of $\mathrm{C} 22$ : of erucic fatty acid (1.1-3\%), which allows the use of varieties Yubilyar and Veles for production of vegetable oil with a high content of unsaturated acids for food purposes. Due to the high content of C18:2 linoleic acid (17-20\%), camelina oil is unstable to oxidation and has a specific taste.

Common varieties of white mustard and oil radish do not fully satisfy the oil and fat industry requirements in terms of the content of essential (allyl) oil and the high content of C22:1 erucic acid in crop seeds.

As a result of the analysis and profitability calculations, it can be noted that cultivation of all studied oilseeds, such as spring rape, spring colza, spring camelina, white mustard and oil radish is very profitable for agricultural production.

\section{References}

1. V.G. Scherbakov, Biochemistry and commodity science of oilseeds (Kolos, Moscow, 2012)

2. V.M. Kosolapov, I.A. Trofimov, Scientific support of Russian meadow farming, Feed product. 8, 47-48 (2011)

3. A.C. De Marins, D.T. Nava, D. Secco, H.A. Rosa, G. Veloso, Crambe yield as affected by soil physical properties linear and spatial correlations, African J. of Agr. Res. 7(44), 5949-5954 (2012)

4. V. Vasileva, Aboveground to root biomass ratios in pea and vetch after treatment with organic fertilizer, Global J. of Envir. Sci. and Manag. 1(2), 71-74 (2015)

5. J.T. Budin, W.M. Breene, D.H. Putnam, Some compositional properties of camelina (Camelina sativa L. Crantz) seeds and oils, J. of the Amer. Oil Chem. Society 72(3), 309-315 (1995)

6. E.I. Lupova, A.V. Novikova, A.V. Polyakov, D.V. Vinogradov, Yield and chemical composition of oil flaxseeds variety Sanlin, Bull. of Timiryazev Agricult. Acad. 6, 110-119 (2019)

7. B.R. Moser, Camelina (Camelina sativa L.) oil as biofuels feedstock: Golden opportunity or false hope? Lipid Technol. 22(12), 270-273 (2010)

8. E.I. Lupova, E.A. Vysotskaya, D.V. Vinogradov, Improvement of elements of oil flax cultivation technology on gray forest soil, IOP Conf. Ser. Earth and Environmental Sci. 422, 012081 (2020) DOI:10.1088/1755-1315/422/1/012081.

9. A. Sarandhi, P. Saradhi, Proline Accumulation under Heavy Metal Stress, Plant Physiol. 138, 554-558 (1991)

10. T. Zoz, F. Steiner, A. Zoz, Effect of row spacing and plant density on grain yield and yield components, Ciencias Agrar., Londrina 39(1), 393-402 (2018)

11. Jędrzej Nyćkowiak, Jacek Leśny, Janusz Olejnik, Regional carbon uptake of croplands in Poland between 1960 and 2009, Meteorol. Hydrol. Water Manag. 6(1), 67-76 (2018) DOI: https://doi.org/10.26491/mhwm/80505

12. B.A. Dospekhov, Methods of field experiment (with the basics of statistical processing of research results), Textbook for stud. of higher agricult. Ed. institute. in agron. Spec. (Alliance, Moscow, 2011)

13. M.A. Fedin, Methodology of state variety testing of agricultural crops (Moscow, 1985)

14. A.V. Shchur, V.P. Valckho, Effect of different levels agroecological loads on biochemical characteristics of soil, South of Russ.: ecol., development 11(4), 139-148 (2016) DOI:10.18470/1992-1098-2016-4$139-148$

15. F. Fahrudin, I.M. Husni, M. Mahrup, Study of water management on rainfed land in downstream Renggung watershed, Meteorol. Hydrol. Water Manag. 5(1), 29-35 (2017) DOI: https://doi.org/10.26491/mhwm/66692 
16. J. Szturc, A. Jurczyk, K. Ośródka, A. Wyszogrodzki, M. Giszterowicz, Precipitation estimation and nowcasting at IMGW-PIB (SEiNO system), Meteorol. Hydrol. Water Manag. 6(1), 3-12 (2018) DOI: https://doi.org/10.26491/mhwm/76120 